Mercè Bernardo

Universitat de Barcelona (Spain)

Raúl Escalante

Universitat de Barcelona (Spain)

Anna Arbussà

Universitat de Girona (Spain)

\title{
Analysis of the Catalan Haute Cuisine Success: The Role of Education and Network Creation
}

\begin{abstract}
This paper analyses two of the success factors of the Catalan haute cuisine: education and network creation. Fifty-four interviews with Michelin-starred restaurant chefs were done, using two questionnaires, one for each factor studied. Cross-case studies were analysed.

Results show that both factors are important and mutually correlated. Education is important to have the bases to understand and enrich the current cuisine, and also act as a pool of relationships creation. Regarding the second factor, the majority of chefs started their relationships at a professional level and some became personal. A framework of collaboration, respect, admiration and joint objectives are the most highlighted key results. The future of this sector, according to the interviewees, is ensured by the new generations of chefs but also because of the society interest. Additional aspects explaining the success of the cuisine are presented.

To the best of the authors' knowledge, this is one of the first works presenting the success of this cuisine studying these two factors in-depth.
\end{abstract}

Keywords: Haute Cuisine; Michelin Stars; Education; Network Creation; Success Factors

Corresponding author: e-mail: merce.bernardo@ub.edu

Received 26 December 2016 - Accepted 10 May 2017

This is an Open Access article distributed under the terms of the Creative Commons Attribution-Non-Commercial-No Derivatives License (http://creativecommons.org/licenses/by-nc-nd/4.0/), which permits non-comercial re-use and distribution, provided the original work is properly cited, and is not altered or transformed in any way. 


\section{Introduction}

In recent years, the hospitality sector and specifically the gastronomy sector have experienced a great success. Several classifications, awards and quality standards have appeared to proof the success this sector is experiencing (Michelin 2015; The Restaurant Magazine 2015; Bernardo et al. 2017).

All the evaluations of culinary experiences has an important subjective component, however, one of the most internationally accepted classifications in the haute cuisine sector is the Michelin star system. The Michelin Guide, which began as a directory listing garages and petrol stations, evolved into a gourmet guide that is published in eight European country editions (Aubke 2014). Nowadays, the Michelin star rating can be considered synonymous of quality gastronomy (Johnson et al. 2005) and is accepted by the entire gastronomy sector and consumers (Winkler 2008). The inspectors of the Guide award a restaurant into three levels with a maximum of three stars, which means:

- One Michelin star: "a very good restaurant in its category"

- Two Michelin stars: "excellent cuisine, it is worth a detour"

- Three Michelin stars: "exceptional cuisine, it is worth a special trip"

As already mentioned, all the guides have a subjective component; however, the evaluation criteria and the methodology used by Michelin are objective. The most important aspects are quality of the products, mastery of flavour and cooking techniques, the "personality" of the cook in his/her cuisine, value for money and consistency (Gastroeconomy 2015). The inspectors of the guide visit annually the restaurants of the guide and evaluate them acting as anonymous clients. No report or feedback is provided to restaurants and they only know the 
results in a ceremony that the Guide holds once a year. Each year the restaurants are evaluated and can (or cannot) renew the award or achieve a higher recognition (Bernardo et al. 2017). The edition of the Guide for Spain and Portugal began in 1910 and since then the number of restaurants with Michelin stars has not ceased to grow. Internationally, with data from 2015, France leads the world ranking with 603 starred establishments, followed by Japan with 516, Italy with 330 and Germany with 283. In Catalonia, the total number of starred restaurants in 2016 was 50 or equivalently, $29 \%$ of 174 restaurants in Spain. In addition, about $88 \%$ of all the Catalan restaurants awarded in Catalonia are located in the provinces of Girona and Barcelona. This fact is an evidence of a certain geographical concentration of top restaurants in a specific territory, as also noticed in the media, even more since 2013, when El Celler de Can Roca was awarded for the first time as the best restaurant in the world according to the recognised and popular list of "The World's Best 50 Restaurants" (The Restaurant Magazine 2015), the proliferation of culinary news on press, radio and television was overwhelming. The success of the Roca brothers and the rest of starred chefs in Catalonia has contributed to the social role of chefs and spread the wealth and value of the Catalan cuisine (Svejenova et al. 2007). The haute cuisine restaurants have become tools to promote a territory and attract tourists for whom gastronomy plays an important role in their trips (Apicius 2013). Today, the haute cuisine restaurants act as showcases of creativity, design and taste of the culture of a region (Svejenova et al. 2010).

The renowned gastronomic excellence of the current Catalan cuisine is probably the result of several factors, which has mainly been analysed from the perspective of the innovation and creativity process of these chefs (Svejenova et al. 2007, 2010). 
Thus, the aim of this study is to analyse two additional factors not analysed in-depth before for the concentration phenomenon and their impact on the success of the Catalan haute cuisine: education and network creation. These factors together with other aspects such as the society interest, culture, products and territory could explain the geographic concentration of Michelinstarred restaurants in Catalonia (an in-depth analysis could be found in Bernardo et al. 2016).

\section{Success Factors in Restaurants}

Engle (2008) defines success factors as: "the most efficient and effective methods of accomplishing a task or achieving a goal, based on repeatable procedures that have proven themselves over time for large number of organizations" (Engle 2008, 20). Nonetheless, as pointed by Cameron (1986), deciding how to measure business success is always problematic because of the difficulties in defining success.

Several classifications have been proposed for the success factors. Dickinson et al. (1984) classified them into internal and external factors. External factors are those that are beyond the control of the business manager such as economic climate, market conditions and competition (Boardman and Vining 1996; Brotherton and Shaw 1996). In contrast, internal factors involve company's competencies that could be modified and have influence in the likelihood of survival of the business, for example product quality, staff and processes and procedures (Berry et al. 1997).

Taking into account the challenges and difficulties to start a business, and given that a high ratio of start-ups fail, some researchers view survival as the key factor of business success (Van de Ven et al. 1984; Barney 1997; Haber and Reichel 2005). As noted by Van de Ven (1993), entrepreneurship studies should not focus only on behaviours of individuals but also should 
examine external environment. Under this view, some studies have analysed the relationship between external environment and business creation (Reynolds et al. 1994) and bankruptcy (Keeble and Walker 1994), using business survival as a success factor.

In the hospitality sector some researchers have carried out studies and proposed models about specific hospitality success factors. Geller (1985) and Goldman and Eyster (1992) identify and use some of them to the negotiations of hotel, food and beverages leases. Croston (1995) applied success factors theories to define the strengths of a successful hospitality businessman/businesswoman and make succeed hotels.

Most of the studies have focused on hotels but Parsa et al. $(2005,2011)$ and Camillo et al. (2008) have proposed specific models for the restaurant sector. Parsa et al. $(2005,2011)$ designed a model to improve the likelihood of success in American restaurants and Camillo et al. (2008) added emotional factors to Parsa et al. (2005, 2011)'s model for independent restaurants in San Francisco. Karim et al. (2011) identified the success factors of the little Malaysian restaurant sector in order to help owners focusing on their specific problems.

Camillo et al. (2008) suggested a classification of success and failure factors for independent restaurants in Northern California. According to them, restaurant success or failure hinges on five groups: (1) strategic decisions, (2) competitive factors, (3) marketing, (4) resources and capabilities, and (5) owner-manager or chef traits. All the success factors obtained from the review are classified in Table 1 according to the dimensions proposed by Camillo et al. (2008). All of them are described below.

The first dimension, strategic decisions, refers to those involving a substantial amount of resources and/or generating subsequent decisions. They are complex and difficult to structure and are not a routine, as they are taken occasionally, even once. Strategic decisions are normally 
top management responsibility and are usually taken after thoroughly studied. Decisions such as the location (Kotler et al. 1996; Parsa et al. 2005, 2011; Wang et al. 2011) or the business plan (Perry 2001; Parsa et al. 2005; Camillo et al. 2008; Cabrera 2015) cannot be changed in the short time. These factors, such as location, are important indicators because constitutes a means of attracting many costumers (Yang et al. 2013). Nevertheless, a strategic location is insufficient to guarantee success if other factors, such as management, are inefficient or poor (Rey-Martí et al. 2016).

The second dimension, competitive factors, joins together all factors that influence the competitive position of a restaurant in the sector. The relationships with competitors (Kotler et al. 1996) as well as the performance (Ottenbacher 2007) are key elements to succeed in the restaurant sector. Mandabach et al. (2011) classified the factors between external environment (general for all the companies of an economy and specific for the restaurant sector) and internal environment (operational factors of a particular restaurant), similarly to Dickinson et al. (1984)'s classification.

The third dimension is marketing and involves all activities and procedures related to customer satisfaction. In the restaurant sector the two most important variables are price (Parsa et al. 2005; Gupta et al. 2012; Agarwal and Dahm 2015) and loyalty (Kotler et al. 1996; Agarwal and Dahm 2015). In some cases a strong brand is also important but often depends on the parent company, which is out of the scope of this study (Itthiopassagul et al. 2009; Vazifehdust et al. 2011). Some of the success factors proposed, such as customer satisfaction (Brown et al. 2014; Jacob et al. 2014) and quality standards (Bernardo et al. 2017) are currently analysed in the literature but more research is needed as well as for innovation (Ottenbacher 2007) and creativity (Balazs 2002; Stierand 2012). 
The fourth group of factors is labelled as resources and capabilities. It aims to identify the factors that differentiate the restaurants from the rest and can provide a competitive advantage. Resources are all the assets that the restaurant has to carry out its actions. These can be physical, technological, human and organizational (Détrie 1995). The restaurant facilities (Mamalis 2009) and the physical environment (Gupta et al. 2012) are examples of key resources for the restaurant. Capabilities are skills (individual or collective) that allow a restaurant to perform specific activities and organizational routines (Détrie 1995). Cost controls (Schmidgall et al. 2002; Agarwal and Dahm 2015), food quality (Parsa et al. 2005; Gupta et al. 2012) and service quality (Enz 2004; Gupta 2012; Chin and Tsai 2013) are necessary capabilities in the restaurant sector.

The last dimension proposed by Camillo et al. (2008) is owner-manager or chef features. Originally this construct did not include chef traits but in most of restaurants the kitchen staff has an important role for the success of the establishment, as a matter of fact they are responsible for the service. Both business experience (Lee 1987; Haswell and Holmes 1989; Sharlit 1990; Camillo et al. 2008; Agarwal and Dahm 2015) and culinary experience (Agarwal and Dahm 2015) are basic characteristics for a successful manager. An honest, dedicated and determined leadership (Camillo et al. 2008) is also commonly pointed out by successful restaurateurs.

\section{Haute Cuisine as a Proposed Dimension}

It has been detected that, according to the existing literature, Camillo et al. (2008)'s classification is not covering all the success factors and, therefore, it has been decided to add an extra dimension named haute cuisine (see also Table 1). It refers to the specific success factors of the high-quality restaurants. Johnson et al. (2005) identified four success factors of 
thirty-six restaurants having two or three Michelin stars over a period of ten years in Europe. The key factors attributed to the haute cuisine restaurants are: (1) investment and investment types, (2) sources of financing, (3) pursuit of excellence and (4) culinary craftsmanship involved. The first two refer to the financial success of the restaurant while the pursuit of excellence and the culinary craftsmanship are related to qualitative goals.

Although the restaurant location has been analysed in the literature (Parsa et al. 2005, 2011; Wang et al. 2011; Tzeng et al. 2002), most of the studies are focused on the term location as a precise place in a city. Therefore, one research line to be developed is to analyse the role of a restaurant location in a broadly meaning. Each location has specific factors that are difficult to imitate in other places that are related to sociocultural and economic characteristics of its inhabitants, networking and resources availability, among others. Identifying these specific factors and characteristics of a region may help to understand the influence of location in the success of restaurants. Related to this, another factor that could be studied is association (Parsa et al. 2011), weather it is formal or informal.

Related also with location is the geographical concentration. Several factors can explain the geographic concentration of restaurants in a specific territory; hence it can be divided into two groups of factors. On the one hand the internal factors, related to the circumstances of the chef, such as his/her education (Lee 1987; Haswell and Holmes 1989; Sharlit 1990; Agarwal and Dahm 2015) or his/her personality (Kouzes and Posner 2006; Camillo et al. 2008). On the other hand, the external factors those are beyond chef's control. The specific culture and the economic environment of where the restaurant is located (Kotler et al. 1996; Parsa et al. 2005, 2011; Wang et al. 2011) and the social networks created among chefs (Parsa et al. 2011) and their impact on the sector and restaurants are examples of research gaps in this dimension. 


\section{Journal of Evolutionary Studies in Business JESB}

Table 1. Success factors in the restaurant sector proposal and their dimensions

\begin{tabular}{|c|c|c|}
\hline Dimensions & Brief description & Supporting Literature \\
\hline \multicolumn{3}{|l|}{ Strategic decisions } \\
\hline Location & Place of the restaurant & $\begin{array}{l}\text { Kotler et al. (1996); Parsa et al. (2005,2011); } \\
\text { Wang et al. (2011) }\end{array}$ \\
\hline Marketing and Business plan & Long-term plans that fix restaurant objectives & $\begin{array}{l}\text { Perry (2001); Parsa et al (2005); Camillo et al. } \\
(2008) ; \text { Cabrera (2015) }\end{array}$ \\
\hline Size & Physical dimensions, capacity & Gaskill et al. (1993); Parsa et al. (2011) \\
\hline Affiliation & Belonging to a group or association & Parsa et al. (2011) \\
\hline Quality and environmental standards & Management systems implemented & Llach et al. (2013) \\
\hline Differentiation strategy or Theme & Specifications or type of restaurant & $\begin{array}{l}\text { Kotler et al. (1996); Camillo et al. (2008); Gupta } \\
\text { et al. (2012) }\end{array}$ \\
\hline \multicolumn{3}{|l|}{ Competitive factors } \\
\hline Competence & Adequacy in the restaurant sector & Kotler et al. (1996) \\
\hline $\begin{array}{l}\text { External environment (general and } \\
\text { specific) }\end{array}$ & $\begin{array}{l}\text { Variable outside the control of the restaurant owner: economic } \\
\text { climate, market conditions and competitors }\end{array}$ & Mandabach et al. (2011) \\
\hline $\begin{array}{l}\text { Internal environment (operational and } \\
\text { personal) }\end{array}$ & $\begin{array}{l}\text { Controllable variables that influence the restaurant likelihood of } \\
\text { survival }\end{array}$ & Mandabach et al. (2011) \\
\hline Customers & Typology of people who come to the restaurant, economic status & Mandabach et al. (2011) \\
\hline Management of restaurant & How the restaurant is directed & Mandabach et al. (2011) \\
\hline Positive goals & Favourable and optimistic objectives & Mandabach et al. (2011) \\
\hline Philosophies & Principles and values applied to the restaurant & Parsa et al. (2005); Mandabach et al. (2011) \\
\hline Market performance & Behaviour of the restaurant in the marketplace & Ottenbacher (2007) \\
\hline Financial performance & Results of the restaurant operations in monetary terms & Ottenbacher (2007) \\
\hline Employee performance & Results in workers activities and the way they were executed & Ottenbacher (2007) \\
\hline Transportation & Availability of raw materials and its displacement & Tzeng et al. (2002) \\
\hline
\end{tabular}

\section{Online ISSN: 2385-7137}

http://revistes.ub.edu/index.php/JESB
COPE Committee on Publication Ethics Creative Commons License 4.0 @creative 


\section{Journal of Evolutionary Studies in Business JESB}

\begin{tabular}{|c|c|c|}
\hline Commercial area & Location in an area with commercial activity & Tzeng et al. (2002) \\
\hline \multicolumn{3}{|l|}{ Marketing } \\
\hline Market driving pricing & Ability to influence in the prices of the market & $\begin{array}{l}\text { Parsa et al. (2005); Gupta et al. (2012); Agarwal } \\
\text { and Dahm (2015) }\end{array}$ \\
\hline Loyal patrons & Ability to build customer loyalty & Kotler et al. (1996); Agarwal and Dahm (2015) \\
\hline Marketing strategies & Methodologies to achieve marketing goals & Balazs (2002); Brown et al. (2014) \\
\hline Market oriented strategy & Focus the marketing activities on the customer & Brown et al. (2014) \\
\hline Development of a strong brand & Creating a well-known restaurant brand & $\begin{array}{l}\text { Itthiopassagul et al (2009); Vazifehdust et al. } \\
\text { (2011) }\end{array}$ \\
\hline \multicolumn{3}{|l|}{ Resources and capabilities } \\
\hline Cost controls & Active application of procedures to limit costs & $\begin{array}{l}\text { Schmidgall et al. (2002); Agarwal and Dahm } \\
(2015)\end{array}$ \\
\hline Positive customer relationships & Having affinity with the customer & $\begin{array}{l}\text { Kotler et al. (1996); Camillo et al. (2008); Jacob et } \\
\text { al. (2014) }\end{array}$ \\
\hline Service quality & Staff treatment & $\begin{array}{l}\text { Enz (2004); Gupta et al. (2012); Chin and Tsai } \\
(2013)\end{array}$ \\
\hline Family support & Family involvement & $\begin{array}{l}\text { Parsa et al. (2005); Ghiselli et al. (2001); } \\
\text { Strickland (2013) }\end{array}$ \\
\hline Physical ambience & Restaurant atmosphere and cleanliness & Gupta et al. (2012) \\
\hline Food quality & Characteristics and gastronomic level of the food served & Parsa et al. (2005); Gupta et al. (2012) \\
\hline Adaptation to locality & Adjust restaurant features to local requirements & Williams (1997); Mamalis (2009) \\
\hline Interaction with service staff & Communication and relationship with employees & Gupta et al. (2012) \\
\hline Interaction with other customers & Communication and relationship with clients & Gupta et al. (2012) \\
\hline Product served & Quality of the raw materials and processing & Mandabach et al. (2011) \\
\hline Facilities & Characteristics of the restaurant & Mamalis (2009) \\
\hline \multicolumn{3}{|l|}{ Owner-manager/chef features } \\
\hline
\end{tabular}

\section{Online ISSN: 2385-7137}

http://revistes.ub.edu/index.php/JESB
COPE Committee on Publication Ethics Creative Commons License 4.0 @creative 


\section{Journal of Evolutionary Studies in Business JESB}

\begin{tabular}{|c|c|c|}
\hline Leadership & $\begin{array}{l}\text { Ability to achieve support of the staff in the accomplishment of } \\
\text { restaurant tasks }\end{array}$ & Kouzes and Posner (2006); Camillo et al. (2008) \\
\hline Emotional traits & Personal motivations & Camillo et al. (2008) \\
\hline Competent management & Appropriate way to run the restaurant & $\begin{array}{l}\text { Lee (1987); Haswell and Holmes (1989); Sharlit } \\
\text { (1990); Agarwal and Dahm (2015) }\end{array}$ \\
\hline Prior business experience & Previous business opportunities & $\begin{array}{l}\text { Lee (1987); Haswell and Holmes (1989); Sharlit } \\
\text { (1990);Camillo et al. (2008); Agarwal and Dahm } \\
(2015)\end{array}$ \\
\hline Culinary experience & $\begin{array}{l}\text { Accumulated gastronomic knowledge, especially of practical } \\
\text { matters }\end{array}$ & Agarwal and Dahm (2015) \\
\hline Business acumen & Astuteness and sharpness for restaurant business & $\begin{array}{l}\text { Lee (1987); Haswell and Holmes (1989); Sharlit } \\
(1990)\end{array}$ \\
\hline Family life cycle & Specific family conditions & Parsa et al. (2005); Mandabach et al. (2011) \\
\hline Personal values & Includes ethical, ideological, social and aesthetic beliefs & Brown et al. (2014) \\
\hline Reliability & Ability to be trusted & Chin and Tsai (2013) \\
\hline Empathy & $\begin{array}{l}\text { Ability to identify another's (customers, employees) feelings and } \\
\text { thoughts }\end{array}$ & Chin and Tsai (2013) \\
\hline \multicolumn{3}{|l|}{ Haute cuisine } \\
\hline Investment and investment types & Use of funds in gastronomic activities & Johnson et al. (2005) \\
\hline Sources of financing & How the restaurant obtain economic resources for its activities & Johnson et al. (2005) \\
\hline Pursuit of excellence & Philosophy of perfection & Johnson et al. (2005) \\
\hline Culinary craftsmanship involved & Availability culinary artisans & Johnson et al. (2005) \\
\hline
\end{tabular}

Source: Own elaboration based on Camillo et al. (2008)

\section{Online ISSN: 2385-7137}

http://revistes.ub.edu/index.php/JESB
COPE Committee on Publication Ethics Creative Commons License 4.0 @ccreative 
Related to the social networks factor, some authors have pointed out the relationship between cooks and how this relationship makes better sharing of knowledge and also contributes to the success of the sector (Aubke 2014; Aldamiz-Echevarría et al., 2014) but more research and analysis is needed in order to explain the concentration phenomenon.

Finally, it should be mentioned that all these factors are not independent. For instance, continuous improvement is closely related to both internal and external factors. It means that restaurant location and its environment may influence the networks created with other restaurants and chefs and vice versa. Therefore the professional and personal relationships among chefs can be an enabler for the emergence of successful restaurants in a region or country, as well as how education on culinary arts, governmental support, etc.

Thus, the aim of this study is to analyse two additional factors not analysed in-depth before for the concentration phenomenon and their impact on the success of the Catalan haute cuisine: education and network creation. These two factors come from the literature review and have been already analysed by some authors. Nevertheless, to the best of the authors' knowledge, none of them have used these factors to explain the geographic concentration of haute cuisine in a specific territory. The methodology used to test these two factors is presented in the next section.

\section{Methodology}

In this section both the participants' selection and data collection are explained.

\section{Participants'selection}

In order to achieve the research objective, the participants' selection was based on an existing and accepted sample of restaurants, which is the Michelin-starred restaurants list 2013 in 
Catalonia (Michelin 2015). As explained previously, this region was selected because of its high number of awarded restaurants but also because two of them, el Bulli and El Celler de Can Roca, have been ranked in the top five positions of the World's 50 Bests Restaurants in recent years.

A pilot test with the most awarded restaurants was performed and additional chefs were added, those who did not have a Michelin star in 2013 but had had in the past and contributed to the success of the sector. The final sample was built up with 54 participants: 49 interviewees belonged to Michelin-starred restaurants in 2013 (50 chefs), three chefs with no star in 2013, but whose restaurants had, and the director of the Alicia Foundation, because of its key role in the sector.

Although some changes in the list occurred during the study (some restaurants lost the star or some chefs changed the restaurant), it was decided not to change it to avoid losing data validity.

\section{Interviews}

Data were collected by interviews, thus, applying a qualitative methodology (Denzin and Lincoln 2011). Interviews allow collecting more in-depth information about the phenomenon analysed (Creswell 2013).

Two different semi-structured questionnaires (Yin 2009) were used to collect data for each of the analysed factors. The advice of experts in the field was requested to review both questionnaires. The first questionnaire is about the education of each participant and the aspects asked were five:

- Courses longer than 6 months, in which, for example, the cooking vocational and education training courses were mainly classified. 
- Shorter courses more focused on specialising some aspects of the cooking process, such as deserts, chocolate, etc.

- Practicum in restaurants

- Working experience in restaurants

- Conferences and seminars participation

In addition, at the end of the questionnaire, participants were asked to rate these aspects based on the importance they give to them when analysing the education portfolio of a chef. Also, an open question asked for other aspects not considered in the questionnaire that could be important to be highlighted.

For the second factor analysed, network creation, another questionnaire was applied and consisted on two main blocks: relationship among two and three Michelin-starred restaurants and relationship among one Michelin-starred restaurants. This differentiation was done because it was considered that the first group of chefs was the spill over of the sector and more information about their relationship was collected. The length of the relationship was also asked. The aspects analysed in this questionnaire were:

- Relationship with chefs of restaurants with two and three Michelin stars (personal and professional)

- Relationship with chefs of restaurants with one or none Michelin stars (personal and professional)

- Geographic concentration (interviewee's opinion on the reasons of this concentration)

- Future

The protocol applied in the interview has followed the steps shown in figure 1. All restaurants awarded with Michelin stars in 2013 were contacted by e-mail with the presentation of the 
project. The following step was contacting each restaurant by telephone to arrange the appointment. A pilot test was performed in July 2013 in one of the restaurants to validate the content of the questions and measure the time needed to perform both questionnaires.

The mean duration of each interview was 60 minutes to complete both questionnaires. In the restaurants with two and three Michelin stars, the interviewing team was built up with two members and in the restaurants with one or none Michelin star the interviewer was one researcher (Yin 2009). All the interviews were recorded and only one chef asked for not being recorded. The field work started in July 2013 and finished in December 2014. Fifty-one interviews were done face-to-face, two were self-reported and 1 was done through Skype.

As shown in figure 1, a case study was built for each restaurant and then e-mailed to the chef in order to validate the content (Satolo et al., 2013; Yin 2009).

Figure 1. Protocol of data collection and validation

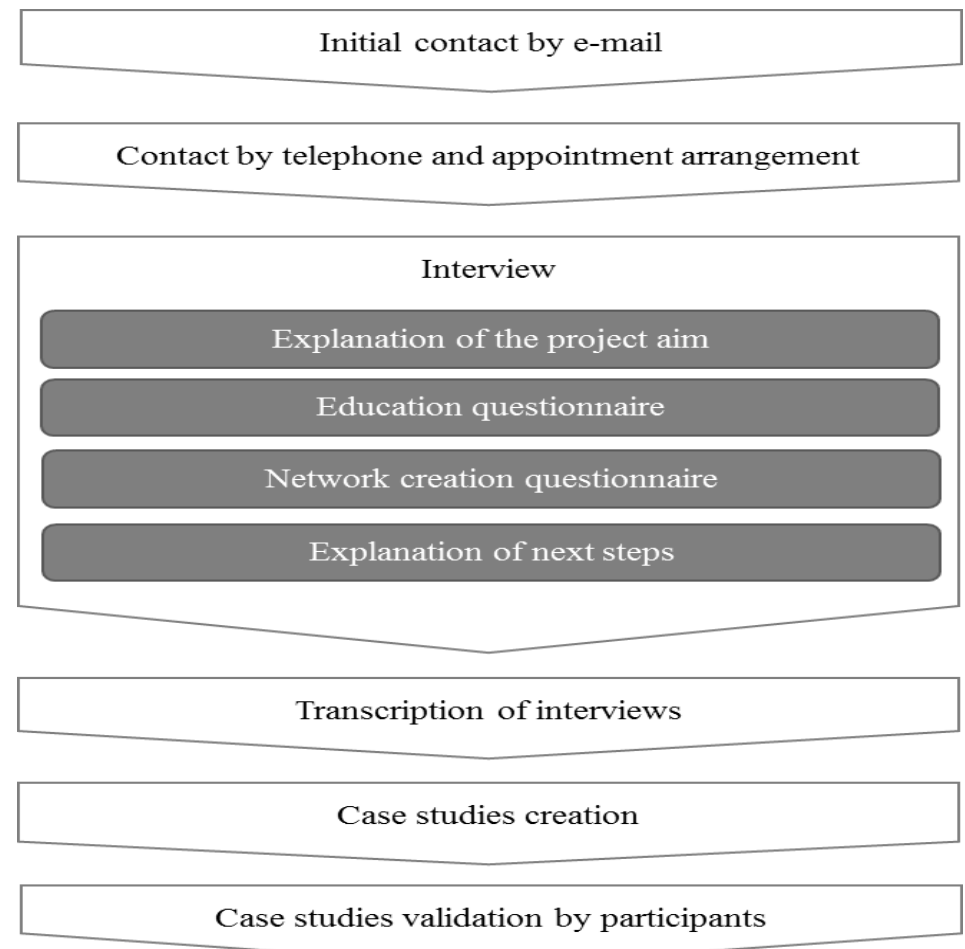

Source: adapted from Satolo et al. (2013) 


\section{Results}

The results of the 54 interviews are summarised below. A more in-depth and wider presentation of the results can be found in Bernardo et al. (2016).

In this section, the results are presented by topic analysed, i.e., first the results regarding the education questionnaire and then the results related to the network creation (relationships, geographical concentration and future of the sector).

\section{Education results}

The majority of the chefs in the sample has attended vocational and education training courses related to cook combined with specialisation courses in a long life learning. The practicum in other restaurants has been highlighted by the majority of participants as well as the labour experience in other restaurants. The difference in this case is with whom these chefs have worked. In other words, the more experienced chefs worked mainly with French chefs while the younger Catalan chefs have worked with other Catalan chefs, thus, the scope of best practices has changed.

The conferences have become one of the most important aspects in the openness of the sector. It should be taken into account that in this sector there are not patent neither intellectual property rights and thus, presenting their creations both new recipes and techniques in conferences has allowed them to register their originality and to share knowledge. Nowadays, all the participants attend and participate as speakers in the most important conferences presenting not only their creations but also explaining their experiences in managing and other practices beyond cuisine. Conferences are also a meeting point for the chefs and sometimes they are the starting point for collaborating. 
Related to this aspect, ethics have been also highlighted, as it is important to reference to the creator of a technique or to whom is the dish based on when presenting. This practice makes the creator receiving the recognition deserved as well as showing the respect that these chefs have one for each other. In addition, it helps in measuring the impact of their creations, i.e., as more chefs use other chefs techniques and dishes, more impact has this chef on the sector.

Finally, the chefs were also asked to rate these factors by importance level. In general terms, courses taken in the vocational and education training programs and labour experience have been the most highlighted. The practicum are also important as well as the conferences. In addition, these chefs mentioned as important to complement the education the fact of visiting other restaurants as clients which allow them sharing knowledge with other chefs and to read gastronomic magazines and online blogs.

\section{Network creation}

\section{Relationships}

The relationships among the sampled chefs could be summarized as good, based on respect and admiration, and where each of them knows their role within the network.

As mentioned previously, the great majority of relationships start because of professional reasons and some of them become personal. The relationship has been analysed more in-depth for those chefs of two and three Michelin-starred restaurants among them and with the rest of the sample.

For these chefs, the relationship among them is close and last for more than 10 years. They meet in conferences very often and are also invited to the same initiatives and events, such as workshops or co-authors of cooking books. They also share members of their teams who want to do a practicum in one of the other restaurants. The relationship with the youngest members 
of this subsample is a bit different because they have not shared the same experiences and because these young chefs are working with other more experienced chefs with whom the relationship is closer.

Regarding the recipes, they can co-create for special events, but they do not do it for their own restaurants. The reason is because recipes are the key element of a restaurant and is what shows the personality and image of the restaurant and thus, this is kept private. Afterwards they would share them in conferences but not during the creation. However, if during the process of creation they have questions, they can ask for recommendations or advice to other chefs and vice versa. The relationship among these chefs and chefs with one or none Michelin star is heterogeneous. The amount of participants in this subsample explains this diversity. This means that in some cases, they are close friends because they studied or worked together and in some others, they have only met once in a conference. Another highlighted practice among these chefs is visiting their restaurants as clients which give them the opportunity of knowing each other but also share knowledge.

In addition, the chefs of the two and three Michelin-starred restaurants act as promoters of the rest of the restaurants, recommending them and making diffusion of their advances. Finally, the chefs of one or none Michelin-starred restaurants declare they follow the evolution and career of the rest of the chefs. The more experienced and awarded chefs are the example to be followed for the sample and they have accepted this role.

The heterogeneity explained in the previous relationship could also be applied to the relationship among chefs of restaurants with one or none Michelin start. In this case, the main reason to start the relationship is because the geographic proximity, as those more close establishes first the relation. The second reason is partnership, i.e., those chefs that met in the 
practicum or working in a restaurant, have maintained the relationship, and also meeting in conferences or other events. The last point of relationship is belonging to specific associations such as Slow Food. These chefs highlighted that they do see each other as friends rather than as competence.

Other aspects have been also analysed, such as the chefs' opinion regarding the geographic concentration or success of the sector and the future they forecast for the sector. They are summarised below.

\section{Geographic concentration}

The participant chefs classified the success of the sector in seven main factors and they are explained below. All the factors have been considered with the same level of importance:

- Great chefs' contribution

The great majority of the sample highlighted that the tipping point on the evolution has been Ferran Adrià, one of the most outstanding Catalan chefs. He had been able to experiment with different products and techniques, he has created the novelty and shared it and this has given the rest the opportunity to open and to try new things.

Other chefs continued with this behaviour, such as Santi Santamaria, Carmen Ruscalleda or Joan Roca, working hard and contributing positively to the sector during a long period of time, mainly in two different ways: opening the Catalan cuisine to the world and acting as knowledge transfer catalysers among the sector trough their transparency.

- Gastronomic culture, interest for gastronomy and socioeconomic level

Catalan society has always been very open to new experiences in gastronomy and interested in knowing these restaurants. This has also been possible for the socioeconomic level of this society which has been able to afford this type of cuisine. 
In addition, the culture and tradition are closely related to cuisine as all the celebrations are around the table.

- Products and territory

The territory provides a huge array of different products from the sea, mountains, orchards, etc., and these products are of a high quality. There is collaboration with the local farmers to have the best products possible.

All this variety gives the possibility to cook many different dishes with local products although they are also open to introduce new products from other cultures.

- The influence of the French cuisine

The proximity of Catalonia with France has been important as some chefs have made the practicum or worked in French restaurants.

\section{- Education}

The role of cooking schools or vocational and education training programs, courses and practicums are also crucial to explain the success. Each generation is better trained and prepared on cooking and this is ensuring a good future too.

- The new generation of chefs

This is related to the previous factor, as the younger chefs have learnt from Catalan chefs and have followed their steps. This generation tries to improve their former generation but looking also to the past to enrich the future.

- The socialization of the cuisine

This means putting the haute cuisine closer to the society. Nowadays, some of these restaurants have prepared more affordable menus to arrive to other clients but also, the role of the media 
has made these restaurants more known. This makes people from different levels of socioeconomic characteristics to visit these restaurants to celebrate events.

Figure 2 relates the factors analysed which contribute to the success of the sector.

Figure 2. Analysed success factors of the Catalan haute cuisine



The expected future

One of the most highlighted aspects has been the importance of acting with responsibility.

The other, is to take profit from the role of the media in the impact of this cuisine on the society. Media have been very important to make this sector well-known for the society and professionals and this should be maintained and improved. More and more specialized magazines and periodical publications on gastronomy and haute cuisine are available not only 
for professionals but also for the society in general and managing this relationship is also important for the sustainable success of the sector.

Related to the sustainability but from the economic point of view, is another aspect to be improved in the future. Make these restaurants achieving good economic results to be able to concentrate in the core business will be important. A great number of chefs have diversified their businesses in order to increase their incomes such as consultancy, opening new related business, etc.

New generations of chefs are also ensuring the continuity of the sector, who have learnt from the best and are following their steps.

The touristic framework as well as the participation and interest of the society will be needed to ensure this positive and promising future.

\section{Conclusions}

This paper aimed to analyse two factors which could explain the success of the Catalan haute cuisine shown by the high geographical concentration of Michelin-starred restaurants in this territory: education and network creation. Based on a qualitative methodology in which 54 participants were interviewed and case studies built, the following conclusions could be extracted.

First, the education factor is important itself for the knowledge transfer and creation in the sector but also as a starting point for the network creation. Education on vocational and education training programs have been highlighted as important but also the working experience in other restaurants. These two factors are crucial for a chef's curricula. Another important aspect in education is conferences. These events are giving the chefs the possibility of sharing knowledge 
among peers, to register their creations, to gain recognition and also to establish new connections to enrich the network.

Regarding the relationship among chefs, it has been confirmed that the two and three Michelinstarred restaurants chefs are acting as spill overs for the rest of the sector. They are who represent the sector in different events and platforms but also who promote the sector. Their importance and contribution has been also mentioned by all the participants.

The relationship is based on respect, admiration, recognition, effort, dedication, hard work and collaboration. Each chef contributes to the success of the sector with their possibilities but all are important to explain this phenomenon.

Different subnetworks could be drawn based on geographic proximity, experience, age, education, etc. Regardless these differences, the transparency, collaboration and openness of all the chefs have been mentioned as important aspects. The only aspect not covered by all these characteristics is the creation of recipes. As highlighted, the recipes for their own restaurants are not co-created as they are the sign of their personality and differentiation.

According to these chefs, the geographic concentration could be explained by several factors, such as the products and territory, the interest and culture of society, the influence of great chefs and French chefs, the new generations, the education, and the socialization of gastronomy. All these factors are related among them and transferred to new generations.

The future of the sector is clear for them: positive. A set of aspects will contribute positively to this future: responsibility, society acceptance, education and relationship with the media.

Implications of this project are for the academia, for chefs and also for the government. For the academia because this is one of the first studies, to the best of the authors' knowledge, to analyse the success of haute cuisine based on education and network creation. This opens a new research 
line on this topic to be analysed from different perspectives. Implications for chefs, because this study reinforces their behaviour and encourages them to continue collaborating and maintaining these relationships. Governments now have evidences that promoting collaboration within the sector is a source to create value for the economy and culture of the country. It is worthy to invest on it as it will have impact on complementary sectors such as tourism, which is very important in Spain.

The main limitation of this paper is geographical. Only one territory, with specific characteristics, was analysed not allowing the generalization of the results.

Future research will be based on widening the territories analysed and also analysing more factors conditioning the success of the sector.

\section{References}

Agarwal, Rupali, and Molly J. Dahm. 2015. "Success Factors in Independent Ethnic Restaurants." Journal of Foodservice Business Research 18 (1): 20-33.

Aldamiz-Echevarría, Covadonga, María Soledad Aguirre, and Maria Gloria Aparicio. 2014. "Orígenes, elementos determinantes y resultados de un exitoso proceso de colaboración entre competidores y otros agentes: el cluster de la Alta Cocina Vasca." Cuadernos de Gestión 14 (2): 51-72.

Apicius. 2013. "Cuaderno de Gastronomia y Alta Cocina.” Accessed April 3. http://www.apicius.es/ Aubke, Florian. 2014. "Creative Hot Spots: A network analysis of German Michelin- Starred Chefs." Creativity and Innovation Management 23 (1): 3-14.

Balazs, Katharina. 2002. "Take one entrepreneur: The recipe for success of France's great chefs." European Management Journal 20 (3): 247-259.

Bernardo, Merce, Anna Arbussà, and Raúl Escalante. 2016. Cuina de relacions: anàlisi de la concentració geogràfica de restaurants amb estrelles Michelin a Catalunya. Barcelona: Edicions de la Universitat de Barcelona; Girona: Servei de Publicacions de la Universitat de Girona

Bernardo, Merce, Raúl Escalante, Joan Roca, and Anna Arbussà. 2017. "Gastronomy Management: a comparative analysis of the existing management system standards." International Journal of Quality and Reliability Management 34 (4): 163-175.

Barney, Jay B. 1997. Gaining and sustaining competitive advantages. New York: Addison-Wesley. 
Berry, Leonard L., Kathleen Seiders, and Larry G. Greshan. 1997. "For love and money: The common traits of successful retailers." Managing Service Quality 26 (2): 12-14.

Boardman, Anthony E., and Aidan R. Vining. 1996. "Defining your business using product customer matrices." Long Range Planning 29 (1): 38-48.

Brotherton, Bob, and Jane Shaw. 1996. "Towards and identification and classification of critical success factors in UK hotels." International Journal of Hospitality Management 15 (2): 113-135.

Brown, Desmond, Kim Spillman, Min-Young Lee, and Ying Lu. 2014. "Factors Influencing Small Tourism Business Performance: The Case of Central Kentucky, United States." Journal of Hospitality Marketing and Management 23 (7): 768-789.

Cabrera, Carles. 2015. El Celler de Can Roca: generando valor en empresas de servicios. Barcelona: Librooks.

Cameron, Kim S. 1986. "Effectiveness as paradox: consensus and conflict in conceptions of organizational effectiveness." Management Science 32 (5): 539-553.

Camillo, Angelo A., Daniel J. Connoly, and Woo Gon Kim. 2008. "Success and failure in Northern California: Critical success factors for independent restaurants." Cornell Hospitality Quarterly 49 (4): 364-380.

Chin, Jiung-Bin, and Chih-Hsin Tsai. 2013. "Developing a service quality evaluation model for luxurious restaurants in international hotel chains." Total Quality Management and Business Excellence 24 (9-10): 1160-1173.

Creswell, John W. 2013. Qualitative inquiry and research design. Choosing among five approaches. $3^{\text {rd }}$ edition. California, USA: Sage Publications, Inc., Thousand Oaks.

Croston, Frank J. 1995. Hotel profitability critical success factors. Accounting and finance for the international hospitality industry. Oxford: Butterworth Heinemann.

Denzin, Norman K., and Yvonna S. Lincoln. 2011. "Introduction: the discipline and practice of qualitative research.” In The Sage Handbook of Qualitative Research, edited by Denzin, Norman K., and Yvonna S. Lincoln, 1-19. London: Sage.

Détrie, Jean Pierre, ed. 1995. Strategor. Estrategia, estructura, decision, identidad: política general de empresa. Barcelona: Masson.

Dickinson, Roger A., Charles R. Ferguson, and Sumit Sircar. 1984. "Critical Success Factors and Small Business." American Journal of Small Business 8 (3): 49-57.

Engle, Paul. 2008. "Validating best practices." Industrial Engineer 40 (11): 20.

Enz, Cathy A. 2004. "Issues of concern for restaurant owners and managers." Cornell Hotel and Restaurant Administration Quarterly 45 (4): 315-332.

Gaskill, LuAnn Ricketts, Howard E. Van Auken, and Ronald A. Manning. 1993. "A factor analytic 
study of the perceived causes of small business failure." Journal of Small Business Management 31 (4): 18-31.

Gastroeconomy. 2015. "El portal de gastronomía empresarial y tendencias en food culture." Accessed March 10. http://www.gastroeconomy.com/2015/11/que-hay-que-hacer-para-tener-una-estrellamichelin

Geller, A. Neal. 1985. "Tracking the critical success factors for hotel companies." Cornell Hotel and Restaurant Administration Quarterly 25 (4): 77-81.

Ghiselli, Richard F., Joseph M. La Lopa, and Billy Bai. 2001. "Job satisfaction, life satisfaction and turnover intent of food service managers." Cornell Hotel and Restaurant Administration Quarterly, 42 (2): 28-37.

Goldman, Keith L., and James J. Eyster. 1992. "Hotel F\&B leases: The view from the restaurant." The Cornell Hotel and Restaurant Administration Quarterly 33 (5): 72-83.

Gupta, Saranjit, Samrat Dasgupta, and Ranjan Chaudhuri. 2012. "Critical success factors for experiential marketing: Evidences from the Indian hospitality industry." International Journal of Services and Operations Management 11 (3): 314-334.

Haber, Sigal, and Arie Reichel. 2005. "Identifying performance measures of small ventures: the case of the tourism industry." Journal of Small Business Management 43 (3): 257-286.

Haswell, Stephen, and Scott Holmes. 1989. "Estimating the small business failure rate: A reappraisal." Journal of Small Business Management 27 (3): 68-74.

Itthiopassagul, Pannapachr, Paul G. Patterson, and Bhuminan Piyathasanan. 2009. "An emerging southeast Asian brand: MK Restaurants." Australasian Marketing Journal 17 (3): 175-181.

Jacob, Céline, Nicolas Guéguen, and Gaëlle Boulbry. 2014. "Using verbal attention to enhance restaurant customer satisfaction and behaviour." International Journal of Hospitality Management 39:50-52.

Johnson, Colin, Bernard Surlemont, Pascale Nicod, and Frederick Revaz. 2005. "Behind the stars: A concise typology of Michelin restaurants in Europe." Cornell Hotel and Restaurant Administration Quarterly 46 (2): 170-187.

Karim, M. Shahrim, Mohiddin Othman, Nurhasmilialisa Abdul Halim, and Hamdin Salleh. 2011. "Evaluating the Critical Success Factors of Restaurants in Kuala Lumpur." Paper presented at the 29th EuroCHRIE Annual Conference, Dubrovnik, Croatia, October 19-22.

Keeble, David, and Sheila Walker. 1994. "New firms, small firms and dead firms: spatial patterns and determinants in the United Kingdom." Regional Studies 28 (4): 411-428.

Kotler, Phillip T., John T. Bowen, and James Makens. 1996. Marketing for hospitality and tourism. Uper Saddle River: Prentice Hall. 
Kouzes, James M., and Barry Z. Posner. 2006. A leader's legacy. San Francisco: Jossey-Bass.

Lee, Daniel R. 1987. "Why some succeed where others fail." Cornell Hotel and Restaurant Administration Quarterly, 28 (32): 33-37.

Llach, Josep, Jordi Perramon, María del Mar Alonso-Almeida, and Llorenç Bagur-Femenías. 2013. "Joint impact of quality and environmental practices on firm performance in small service businesses: An empirical study of restaurants." Journal of Cleaner Production 44:96-104.

Mamalis, Spyridon. 2009. "Critical success factors of the food service industry." Journal of International Food and Agribusiness Marketing 21 (2-3): 191-206.

Mandabach, Keith H., Mohammad Ashar Siddiqui, Gregory F. Blanch, and Dawn M. Vanleeuwen. 2011. "Restaurant viability: Operations rating of contributing success factors." Journal of Culinary Science and Technology 9 (2): 71-84.

Michelin. 2015. La guía MICHELIN España and Portugal. Madrid: Michelin.

Ottenbacher, Micheal. 2007. "Innovation Management in the Hospitality Industry: Different Strategies for Achieving Success." Journal of Hospitality \& Tourism Research 31 (4): 431-454.

Parsa, H.G., John Self, David Njite, and Tiffany King. 2005. "Why restaurants fail." Cornell Hotel and Restaurant Administration Quarterly 46 (3): 304- 322.

Parsa, H.G., John Self, Sandra Sydnor-Busso, and Hae Jin Yoon. 2011. "Why restaurants fail? Part II: The Impact of Affiliation, Location, and Size on Restaurant Failures." Journal of Foodservice Business Research 14 (4): 360- 379.

Perry, Stephen C. 2001. "The relationship between written business plans and the failure of small business in the U.S." Journal of Small Business Management 39 (3): 201-208.

Rey-Martí, Andrea, Domingo Ribeiro-Soriano, and Daniel Palacios-Marqués. 2016. "Entrepreneurial attributes of human capital and contingency factors in the culinary tourism." International Entrepreneurship and Management Journal 12 (1): 67-85.

Reynolds, Paul, David J. Storey, and Paul Westhead. 1994. "Crossnational comparisons of the variation in new firm formation rates." Regional Studies 28 (4): 443- 456.

Satolo, Eduardo G., Felipe A. Calarge, and Paulo A. Cauchick Miguel. 2013. "Experience with an integrated management system in a sugar and ethanol manufacturing unit: Possibilities and limitations. " Management of Environmental Quality: An International Journal 24 (6): 710-725.

Schmidgall, Raymond S., David K. Hayes, and Jack D. Ninemeier. 2002. Restaurant financial basics. Hoboken: John Wiley.

Sharlit, Ian. 1990. "Six early warning signs of business failure." Executive Psychology, 26-30.

Stierand, Marc B., and Viktor Dörfler. 2012. "Reflecting on a phenomenological study of creativity and innovation in haute cuisine." International Journal of Contemporary Hospitality Management 24 
(6): 946-957.

Strickland, Paul. 2013. "Examining the Impact of Four Key Cultural Dimensions on Ethnic Restaurants in Victoria in Australia." Asia Pacific Journal of Tourism Research 18 (5): 483-500.

Svejenova, Silviya, Carmelo Mazza, and Marcel Planelles. 2007. "Cooking up change in haute cuisine: Ferran Adrià as an institutional entrepreneur. " Journal of Organizational Behavior 28 (5): 539561.

Svejenova, Silviya, Marcel Planelles, and Luis Vives. 2010. "An Individual Business Model in the Making; a Chef's Quest for Creative Freedom. " Long Range Planning 43 (2-3): 408-430.

"The World's 50 Best Restaurants." The Restaurant Magazine, June 1. Accessed June 15, 2015 http://www.theworlds50best.com/

Tzeng, Gwo-Hshiung, Mei-Hwa Teng, June-Jye Chen, and Serafim Opricovic. 2002. "Multicriteria selection for a restaurant location in Taipei." International Journal of Hospitality Management 21 (2): 171-187.

Van de Ven, Andrew H. 1993. "The development of an infrastructure of entrepreneurship." Journal of Business Venturing 8 (3): 211-230.

Van de Ven, Andrew H., Roger Hudson, and Dean Shroeder. 1984. "Designing new business start-ups: entrepreneurial, organizational, and ecological considerations." Journal of Management 10 (1): $87-107$.

Vazifehdust, H., Mohammad Javad Taghipourian, and A.F. Ahmadian. 2011. "Y generation, combination generation and perceptions differentials from brand components in Iranian chain restaurants." European Journal of Scientific Research 60 (1): 86-94.

Wang, Tien-Chin, Shu-Chen Hsu, and Hui-Chen Chen. 2011. "Using the group decision making matrix in the selection of business location." Paper presented at International Conference on Machine Learning and Cybernetics, Guangxi, China, July 10-13.

Williams, Monci J. 1997. "Agility and Learning: An Essential for Evolving Organizations--and People." Harvard Management Update 2 (5): 3-5.

Winkler, August. 2008. 100 Beste Köche. Germany: Neuer Umschau Buchverlag.

Yang, Yang, Tim Fik, and Jie Zhang. 2013. "Modeling sequential tourist flows: where is the next destination?." Annuals of Tourism Research 43:297-320.

Yin, Robert K. 2009. Case Study Research. Design and Methods. Thousand Oaks, CA: Sage Publications Inc.

This is an Open Access article distributed under the terms of the Creative Commons Attribution-Non-Commercial-No Derivatives License (http://creativecommons.org/licenses/by-nc-nd/4.0/), which permits non-comercial re-use and distribution, provided the original work is properly cited, and is not altered or transformed in any way. 